\title{
Mpalive-Hangson Msiska, Postcolonial Identity in Wole Soyinka
}

\section{Christiane Fioupou}

\section{(2) OpenEdition \\ 1 Journals}

Electronic version

URL: https://journals.openedition.org/ces/8359

DOI: $10.4000 /$ ces.8359

ISSN: 2534-6695

\section{Publisher}

SEPC (Société d'études des pays du Commonwealth)

\section{Printed version}

Date of publication: 1 September 2010

Number of pages: 121-122

ISSN: 2270-0633

\section{Electronic reference}

Christiane Fioupou, "Mpalive-Hangson Msiska, Postcolonial Identity in Wole Soyinka", Commonwealth Essays and Studies [Online], 33.1 | 2010, Online since 11 December 2021, connection on 20 January 2022. URL: http://journals.openedition.org/ces/8359 ; DOI: https://doi.org/10.4000/ces.8359

This text was automatically generated on 20 January 2022.

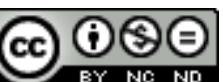

Commonwealth Essays and Studies is licensed under a Licence Creative Commons Attribution - Pas d'Utilisation Commerciale - Pas de Modification 4.0 International. 


\title{
Mpalive-Hangson Msiska, Postcolonial Identity in Wole Soyinka
}

\author{
Christiane Fioupou
}

\section{REFERENCES}

Mpalive-Hangson Msiska. Postcolonial Identity in Wole Soyinka. Amsterdam/ New York: Rodopi, Cross/Cultures 93, 2007. xxxvii + 176 pages. ISBN 978-90-420-2258-4. € 44 / US \$ 59

1 In this study, Mpalive-Hangson Msiska demonstrates that "What Soyinka enacts in all his works is a postcolonial dialectic." (164). The introduction provides the reader with biographical and literary information about Soyinka and the critical reception of his works. The five ensuing chapters explore postcolonial issues in the light of his major plays, novels, or poems published in the 1960s and 1970s and, more briefly, through some later plays, biographies and essays. The chapter, "Myth, History and Postcolonial Modernity" focuses on two plays (A Dance of the Forests and The Bacchae) and the poem Idanre; the relationship between "Tradition and Modernity" is examined through The Lion and the Jewel, Death and the King's Horseman, and The Swamp Dwellers; "The Banality of Postcolonial Power" analyses the Jero Plays, Kongi's Harvest, Opera Wonyosi, and, more cursorily, A Play of Giants, all satirical plays dealing with power and politics. "The Abyss of Postcolonial Formation" considers two important plays (The Road and Madmen and Specialists) and the poems A Shuttle in the Crypt and Mandela's earth. The final chapter, "Resources for Redemption," deals with a radio play (Camwood on the Leaves), a play (The Strong Breed), and a novel (Season of Anomy). As Msiska's study is clearly aimed at those interested in Soyinka, postcolonial issues and African literature, an index would have been most helpful.

2 Although much of the field has already been coveredby earlier Soyinka criticism, this book will no doubt appeal to students looking for a general introduction to Soyinka's works and to those interested in "theory" and who believe, like Msiska, that Soyinka is 
a true disciple of postcolonial studies, despite his well-known disclaimer. In his Preface, Msiska acknowledges the importance of Biodun Jeyifo's “magisterial” Wole Soyinka: Politics, Poetics, [and] Postcolonialism (2003), which has "moved the discussion of the author's work into the poststructuralist and post-Marxist space" (x), only to later dismiss Jeyifo as a critic who has relinquished ideology in favour of "aporetic troping" (xi). One might beg to differ. Ironically, in the general bibliography, Biodun Jeyifo's "magisterial" book appears under the name of well-known critic Abdul JanMohamed (172). A true case of mistaken (postcolonial?) identity. Other inaccuracies need to be noted: for instance, in A Play of Giants, the playwright's gallery of grisly tyrants is modelled on four well-known dictators, not three - Bokassa-cum-Boky is forgotten (80, $33)$, and Macias Nguema - not Marcus $(33,80)$ - was the President of Equatorial Guinea, not Gabon (80).

Soyinka scholars are likely to remain dissatisfied by Msiska's determination to wedge the Nigerian writer into a postcolonial framework, since this excludes foundational elements of Soyinka's originality. Each play under study is notably summed up in a straightforward, linear way, whereas the play's strength lies precisely in its complex non-linear dramatic construction - an aspect which is consistently ignored. No mention is made of specific theatrical strategies and idioms; for instance, the use of flashbacks and visions, the unsettling presence of the Girl's effigy in The Strong Breed (155), the mendicants' disquieting role-playing and chanting in Madmen and Specialists (127) or the function of flashbacks and possession dance in The Road (112-113). Also, in spite of general statements about "the "discursive hybridisation that Soyinka produces in his work" (28), Msiska misquotes the poet's notes to Idanre, replacing Soyinka's definition of the Möbius strip as a "mathe-magical ring" (Idanre 87) by the very orthodox "mathematical ring" (27). It seems more than a simple typo, as it misses the felicitous oxymoron that perfectly encapsulates Soyinka's ability to re-appropriate an already complex paradoxical figure, a graphic example of hybridisation with its "evolutionary 'kink'," "only an illusion, but a poetic one" (Idanre 87).

The front cover with Soyinka's duplicated photo blurred and warped in a manner which could be seen as disrespectful, perhaps reflects the distorted lens through which his works are viewed when shoehorned into rigid theoretical frameworks. Unfortunately, such an approach fails to do credit to the richness and complexity of Soyinka's texts, their humour and poetry, and to his theatre in performance, another aspect of Soyinka's work that is regretfully absent from Postcolonial Identity in Wole Soyinka.

\section{AUTHORS}

\section{CHRISTIANE FIOUPOU}

Christiane FIOUPOU is a Professor of English at the University of Toulouse-Le Mirail, France. She specialises in African studies, particularly Nigerian and Ghanaian literature. She taught English and African Literature at the University of Ouagadougou (Burkina Faso) for twelve years. She has 
published a monograph on Soyinka, La route: réalité et représentation dans l'œuvre de Wole Soyinka (Rodopi: 1994), and translated two of his plays into French, The Road (La route, Hatier, 1988) and King Baabu (Baabou roi, Actes Sud Papiers, 2005). Her other publications include the French translation of Niyi Osundare's volume of poems, Waiting Laughters /Rires en attente (Présence Africaine: 2004). 